\title{
30
}

Reviews

\section{Metalepsis in Animation: Paradoxical Transgressions of Ontological Levels. By Erwin Feyersinger (Heidelberg: Universitätsverlag Winter, 2017), 164pp.}

Florian Zitzelsberger, University of Passau

DOI: 10.47060/jaaas.v2i1.129

The title of Erwin Feyersinger's Metalepsis in Animation: Paradoxical Transgressions of Ontological Levels provides readers with a first working definition of the narrative phenomenon explored in the book. Following research in literary studies (most prominently Gérard Genette's early deliberations about characters crossing borders between narrative levels) and the further development of metalepsis as a transgeneric and transmedial occurrence in representational media (among others, Werner Wolf's significant contributions to the study of metareference), Feyersinger sets out to contextualize and (re)conceptualize metalepsis within the framework of cognitive narratology, focusing on animated film. In particular, his book is informed by Gilles Fauconnier and Mark Turner's theory of conceptual blending, which assumes that "human beings [are able to] combine differing concepts located in various mental spaces" (78). If classical narratology broadly conceives of metalepsis as a transgression of the divide between, or an amalgamation of, mutually exclusive worlds, conceptual blending, as Feyersinger convincingly demonstrates throughout the second half of his book, enables an approximation of the concept's paradoxical nature from a cognitivist point of view. Metalepsis, accordingly, constitutes "a blend of two conflicting inputs," a conflict which "is not fully resolved in the blend and perceived as a paradox" $(142,146)$. The perceived impossibility of metaleptic transgressions transcends the medium in which these transgressions take place; an analysis of metalepsis thus needs to consider the act of reception, an endeavor facilitated by cognitive narratology. Based on these central premises, I wish to address two points in the following, Feyersinger's examination of metalepsis in animation as well as his work on related "transgressive phenomena," such as TV crossovers and metamorphoses, "that are not perceived as paradoxical" (10).

After a brief general introduction, the book's second chapter offers a concise survey of previous attempts at conceptualizing metalepsis. Feyersinger complements this theoretical overview with examples from various media. While chapter two more specifically focuses on literature and film as the two most prominent subjects of investigation in the study of metalepsis, throughout the rest of the book, the case studies of animated films are supplemented by excursions to other formats such as music videos, cartoons, and even performance art. The diverse corpus of texts not only attests to Feyersinger's intention to develop "theories, typologies, and models that are not restricted to animation alone, but can be applied to other media as well" (146), they also allow for a diachronic perspective on metalepsis in animation. As 
Feyersinger illustrates in his close reading of Romain Segaud and Christel Pougeoise's short film Tim Tom (2002; chapter four), animated films frequently "historicize and fictionalize the technological and psychophysiological basis of animation" (33), which is closely related to the development of the other media discussed in the book. Accordingly, chapter four situates animation within the broader historical context of metareference. Feyersinger argues that, in animation, a "meta-metareferential turn" can be discerned; since animated films are already metareferential, changing media environments and their increasing employment of metareferential devices lead to "metareferential reflections on an already metareferential art form, i.e., meta-metareferences" (33). Even though Tim Tom and Chuck Jones's Duck Amuck (1953; chapter seven) are Feyersinger's only two extensive case studies on metalepsis in animation-both having a particular thematic focus such as the historicization of metareference in animation and the contribution of metalepsis to the integrity of a character-other examples are revisited multiple times, inviting comparison.

Feyersinger's exploration of metalepsis in animation begins with the narratological tradition discussed in chapter two, before turning to the inventive and genuinely auspicious approach of the study, developing a generic model of the conceptual blending of metalepsis (chapter nine). Chapter three proposes a typology consisting of seven elementary types of metalepsis based on Genette's taxonomy of narrative levels, which Feyersinger persuasively adapts to meet the specificities of animated film. He asserts that animation is particularly prone to metareferential structures such as metalepsis since both "are often experimental and feature the transgression of borders: ontological borders in the case of metalepsis; imaginative, aesthetic, or ideological borders in the case of animation" (20). While his analysis of Duck Amuck in chapter seven still largely operates within the typology based on narrative levels (for instance, when describing the relationship between a seemingly omnipotent animator and their drawings, both of which are situated on ontologically different levels), this in-depth case study more importantly applies Fauconnier and Turner's notion of conceptual blending, whose theoretical foundation is curtly touched upon in chapter six, to animated film. Understanding metalepsis in terms of blending allows for metonymic substitutions of inputs such as setting, roles, and costumes (altered by the fictional animator) which, however, are not perceived as disruptions in the identity of Daffy, the animation's protagonist, but as a means of substantiating character integrity. In the process of blending, Feyersinger argues, "connections of related and unrelated concepts are established, and new meaning emerges," a meaning which foregrounds "both the stability of an established character and the spectators' flexibility in constructing the continuity of an identity" (100), again stressing the act of reception. Feyersinger's project therefore goes beyond the general applicability of cognitive narratology to metalepsis as it assesses possible functions of metalepses 
in animation through the pronounced shift toward reception.

Besides addressing metalepsis in animation, the study puts into critical focus other related "world-connecting phenomena" (74) such as TV crossovers (chapter five). While Feyersinger delineates how "transpositions" of elements from one series to another in a crossover "create metalepsis-like effects" (73), he repeatedly emphasizes the promotional purpose of (metaleptic) crossovers. Both metalepsis and crossovers do not necessarily have an anti-illusionistic effect; they do not necessarily foreground deconstructive tendencies readily associated with metareferential structures. Instead, reading both as related concepts fosters an understanding of animation as an artform perpetuating its own generic codes which, indeed, contributes to the commercial appeal of these phenomena. His case study of Duck Amuck similarly responds to an economic argument, for example in the conceptualization of "animated characters as film stars" (99). Instances where Feyersinger moves away from metalepsis as such and turns toward its intersections with related conceptsthis also applies to chapter eight, which considers metamorphosis in animation-are perhaps the most outstanding achievements of the book. These chapters broaden the scope of the study. Even though the title of the book leads to expectations of yet another work exclusively centering on metalepsis, in actuality, Metalepsis in Animation includes additional information on the background and various contexts of both metalepsis and animation which speak to the main approach of the book: the inclusion of metalepsis-like, yet evidently different, concepts mirrors the blending of seemingly disparate inputs, the cognitive process activated in the reception of metalepsis and metamorphosis in animation as well as in the reception of crossovers, which proves to be heuristically sensible in the study of metalepsis. The comparative and contrastive nature of these chapters therefore provides readers with valuable insights into the workings of metalepsis in animation.

Metalepsis in Animation: Paradoxical Transgressions of Ontological Levels in many ways constitutes a convincing contribution to the fields of both animation studies and cognitive narratology, addressing aspects ranging from the genesis of metaleptic effects in animation to, more importantly, the reception and decoding of this phenomenon. While the book does not feature an index, cross-references between individual chapters still make the text reader-friendly and accessible, and establish coherence. In addition, Feyersinger concisely lists and summarizes the central points of his argument throughout the book and includes conclusions for the thematic/analytic chapters of the study. The text is augmented by numerous screenshots from animated films and, in particular in the chapters on conceptual blending, greatly useful illustrations which enhance the overall comprehensibility of the book and strengthen the presentation of Feyersinger's argument. Finally, Metalepsis in Animation not only offers readers ways to rethink transgressive phenomena in 


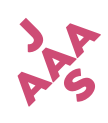

Reviews

animation and other media, it also successfully demonstrates the increment value of cognitive narratology and conceptual blending for the study of the paradoxes of metalepsis.

\section{Paul Austers autobiographische Werke: Stationen einer Schriftstellerkarriere. By Christian Eilers (Heidelberg: Universitätsverlag Winter, 2019), 326pp.}

Matthias Klestil, University of Klagenfurt

DOI: 10.47060/jaaas.v2i1.119

Christian Eilers's book Paul Austers autobiographische Werke: Stationen einer Schriftstellerkarriere turns to an understudied part of Paul Auster's work: his autobiographical writing. Although the writer's oeuvre has been the subject of academic debate for decades, the majority of scholarship has dealt with Auster's novels, sometimes in conjunction with, but more rarely with an explicit focus on, his memoirs. In its attempt to fill this gap, Eilers's book, a comparative analysis of texts identified as "immediate" ("unmittelbare" [4, 307, 314]) autobiographical works, will be of interest to scholars looking for a biographical lens on Auster and readers eager to learn more about the writer's life.

Framed by an introduction and a conclusion, the four thematic chapters of the book, which is based on Eilers's dissertation, consider four texts written by Auster over a period of more than 30 years: White Spaces (1980), The Invention of Solitude (1982), Hand to Mouth (1997), and Winter Journal (2012). In these, Eilers identifies dominant motifs that will be familiar to readers of Auster's fiction, such as the quest for truth, the failures of language, defeat, hermetic space, or solitude, which Eilers links to the author's biography. Methodologically, the study proposes to combine a text-based analysis of its selection of autobiographical texts with a biographical approach (6). Explicitly set against poststructuralist and deconstructivist methods (6), Eilers's readings rely on a traditional focus on the author that takes the selected texts as evidencing Auster's gradual approximation of himself (304), and as fragments of a bigger picture of the man. The study addresses Auster's autobiographical work as a growing whole ("sich stets erweiterndes autobiographisches Gesamtbild" [201]), a notion also conveyed through the images of stages or a mosaic $(194,201,209)$ that suggest a hermeneutic approach to Auster's writing that seeks root causes for the texts' motifs in the author's life $(3,12)$.

The biographical events Eilers reads as formative for Auster's motivic world range from the deaths of his parents and the divorce from his first wife, Lydia Davis, to Auster's years in Paris and his existential crisis in the late 1970s. The latter figures prominently in the first two thematic chapters, which examine the eight-page White 